\title{
EAl Endorsed Transactions

\section{Make blended learning happen: conditions for a successful change process in higher education institutions}

\author{
L. Caporarello ${ }^{1, *}$, A. Iñesta ${ }^{2}$ \\ ${ }^{1}$ Department of Management and Technology, and SDA Bocconi School of Management, Bocconi University, Milano (Italy) \\ ${ }^{2}$ ESADE Center for Educational Innovation, ESADE Business \& Law Schools, Ramon Llull University, Barcelona (Spain)
}

\begin{abstract}
The evolution of technology has influenced and, in some cases pushed, many change projects in any type of industry. Educational institutions have also been influenced by this technological evolution. This has generated some important shifts in the educational paradigm that have consequently lead to some changes in the learning processes. Although elearning represents one of the most important consequences of such educational paradigm evolutions, its relative benefits have still not been fully demonstrated. Thus, a new educational paradigm shift has emerged: blended learning. This phenomenon is not new in the literature, but recently it is increasingly gaining support as the model of the future in higher education, especially in international institutions in constant quest for excellence and innovation in the learning experiences they propose to their learners. How are educational institutions facing the use of technology for educational purposes? How do they have to change in order to be ready for successfully adopting this kind of learning model? In this paper we intend to answer these questions, and to provide some recommendations to educational institutions in order to help them understand how to lead the change processes necessary for blended learning to become a full-fledged reality at their schools.
\end{abstract}

Keywords: blended learning, educational paradigm evolution, learning experience.

Received on 24 January 2016, accepted on 20 May 2016, published on 02 December 2016

Copyright (C) 2016 L. Caporarello and A. Iñesta, licensed to EAI. This is an open access article distributed under the terms of the Creative Commons Attribution licence (http://creativecommons.org/licenses/by/3.0/), which permits unlimited use, distribution and reproduction in any medium so long as the original work is properly cited.

doi: 10.4108/eai.2-12-2016.151716

\section{Introduction}

In recent decades, the evolution of educational paradigms and of technology, in particular of Internet and web-based applications, have been widely discussed in literature. Particularly, technology has evolved exponentially, and this has significantly contributed to increase the pervasiveness of "technologies" at both personal and professional levels. In this context, as it is well known, the use of technology has hugely influenced the evolution of education paradigms. Although many studies and researches have investigated the role and influence of technology for educational purposes, its actual effectiveness is still an open issue $[1,2,3,4]$.

*Corresponding author. Email:leonardo.caporarello@unibocconi.it
In relation to this, a lot of the literature focuses on the characteristics and effectiveness of technology, while it is important to balance both the technological and educational dimensions. In fact, technology cannot be considered to be useful or not in isolation. The contribution of technology can be evaluated based on the way technology is used and applied in a given context [5]. Moreover, the way technology is used depends also on how teachers think about technology [5].

Focusing on the educational context, a first question we intend to address is "are the current technology-enabled learning models, i.e. e-learning, effective enough or a new paradigm in the learning model evolution path is expected to be even more effective?". The effective use of a learning model typically requires some enabling conditions. How are 
educational institutions facing the use of technology for educational purposes? How do they need to change in order to be ready for successfully adopting this kind of learning model?

Leveraging on two bodies of literature, online education and change management, this paper aims at contributing to the managerial debate about technology-enabled learning models. In particular, based on the online educational model literature, we intend to answer the first two above questions; next, referring to the change management literature, we intend to answer the third question, specifically providing some recommendations to educational institutions in order to help them understand how to make the educational paradigm transition happen.

\section{Literature review}

Educational paradigms have continuously evolved over the last 35 years. Analysing their evolution, we can identify three major shifts. The first shift took place in the $1980 \mathrm{~s}$ when the educational process was mainly led by teachers [6, 7]. The second shift arrived in the early 1990s, where the education process focused on the relationship between teachers and learners [8]. The third shift can be traced back to the late 1990s. From then onward the educational process is aiming at fostering the learner-centric focus $[9,10,11$, 12].

During this time, the evolution of technology has played an important role in influencing the shift of educational paradigms. The use of technology for educational purposes has created new concepts and models, e.g. online and distance education, web-based learning, computer-mediated learning, e-learning [13].

Online education is defined as any form of learning that takes place via computer network [14]. Among these new ways of learning, the e-learning model has gained lot of attention in literature in the last 15 years [15]. Nevertheless, there is not a unique and common definition of e-learning. Terry defined e-learning as "the ability to deliver training and education via web technology" [16]. According to Rosenberg, e-learning consists of "the use of Internet technologies to deliver a broad array of solutions that enhance knowledge and performance" [17]. Others (e.g. [18]) defined e-learning as "the use of computer network technology, primarily over or through the Internet, to deliver information and instruction to individuals".

More recently, e-learning has been defined as "a set of models, methodologies, and processes for the acquisition and use of knowledge distributed and facilitated primarily by electronic means" [1].

Compared to the traditional learning models, e-learning offers some important advantages, such as: flexibility, that means participants can self-manage the timing when take the learning content; tracking the learning progress - that means participants can have the possibility to monitor their learning progress through taking quizzes or other evaluation tools and practices, and this also helps them to review some of the content, when necessary; interactions and collaborations among participants and between them and faculty members can be fostered and amplified - this is an effective mechanism to support the creation of a social learning environment where people actively contribute to the creation, discussion and dissemination of knowledge; learning resources can be frequently updated - this makes learning an ongoing process thanks to the sharing of new resources, developed either by participants, faculty or other sources, and also this contributes to make the learning experience even more "fresh" and actual [19, 20, 21].

Moreover, in order to make e-learning a successful experience the following critical success factors are worth mentioning: technology must be perceived as easy to use, otherwise it becomes one of the major obstacles to the elearning process; teaching and learning styles need to be taken into consideration while designing the e-learning experience; learners must perceive the course as useful for them, otherwise people tend to resist in taking the course. Thus, the overall learning experience has to be organized and structured in order to take into consideration all the above advantages and critical success factors and manage them properly $[22,23]$.

Although there are many research studies highlighting the positive effects of e-learning processes, others highlight some relevant pitfalls [24], particularly in terms of its limited capacity to actively engage learners in the educational process, and to make learners feeling to establish a positive relationship with the teacher [25, 26, 27]. In fact, e-learning models seem unable to deliver the expected results [20, 28, 29, 30, 31, 32], lacking some of their most important key success factors that are the sense of presence, the feeling of immediacy, and the dynamicity and fluidity of the learning environment [33].

Thus, as mentioned, while e-learning is widely discussed in the literature, its actual utilization and its impact in terms of learning effectiveness are still an open issues [34].

Following the above discussion, a formal shift in the educational paradigm must be identified and recognized: the blended model. Here the blended model is intended not just as an educational model per se, but as a new wave in the technology-enhanced educational models.

An overview of the evolution of the learning paradigm, from educational and techno-logical perspective is shown in figure 1 .

The blended model provides a learning experience through the integration of different learning methodologies, including face-to-face via technology-enabled environments $[35,36,37,38]$. In the simplest form, the blended learning 
model is the thoughtful integration of online and face-toface-instruction [39].

The blended model is not a new concept in the literature, but recently it has received increased attention among academics and practitioners [40, 41, 42, 43]. Comparing blended to e-learning models it is possible to identify some relevant differences, as they emerge in the literature.

As table 1 synthesizes, learners in the e-learning model perceive a higher instructional difficulty than those in blended learning model. Moreover, in the e-learning setting, learners experience a significant higher workload for their study than those in the blended learning setting. A third relevant aspect is about the learning support that is perceived higher in the blended learning model than in the elearning one.

Moreover, a recent study predicts a relevant percentage of learners will prefer to take courses in blended formats respect to courses in face-to-face setting [44]. According to this study, a large part of learners prefers to take courses in blended model. This phenomenon is as large as $71 \%$ of learners: from 14.1 million in traditional courses enrolment in 2010 to a 4.1 million in 2015.

A recent study [45] conducted over one million learners' responses (2008-2011) analyses the effectiveness of blended learning initiatives with the effectiveness of other ways of learning. The following results emerge: $52 \%$ of respondents rated the blended learning courses they have taken highest as "excellent", while other ways of learning (online and face-to-face courses) were rated as excellent by the $48 \%$ of respondents.

Another important indicator is the withdrawal rate. In the blended courses learners tend to withdraw much lower than they do in other modes of learning.

From a general perspective, learners are positive about the courses that offer flexibility in both time and space. In fact, recently the number of online learning options, including massive open online courses (MOOCs), has widely increased. At the same time, a low level of interaction among learners and between learners and teachers represents one of the main causes of the low completion rates of online courses [46, 47].

Table 1. Some differences between e-learning and blended learning settings

\begin{tabular}{|l|l|l|}
\hline & E-learning & $\begin{array}{l}\text { Blended } \\
\text { learning }\end{array}$ \\
\hline $\begin{array}{l}\text { Perception of } \\
\text { instructional difficulty }\end{array}$ & Higher & Lower \\
\hline Perception of workload & Higher & Lower \\
\hline $\begin{array}{l}\text { Feeling of support for } \\
\text { learning }\end{array}$ & Lower & Higher \\
\hline Withdrawal rate & Higher & Lower \\
\hline
\end{tabular}

This challenge is overcome by the use of blended learning model. Moreover, some authors [48] highlight the importance of learning environments to foster interaction, communication, learning enhancements, and constructivism. The blended learning model is expected to enable these elements. Furthermore, this model has the potential to create a much more reflective learner population, and to extend learning far beyond the boundaries of traditional classrooms.

So, let us explore in the next paragraph the critical success factors for educational institutions interested in adopting this model.

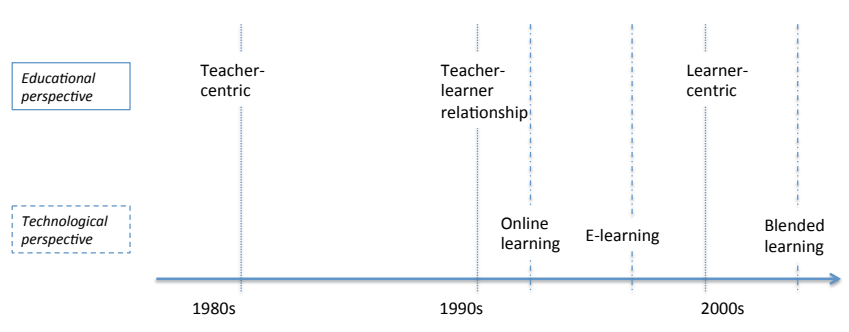

Figure 1. Evolution of the learning paradigm: an educational and technological perspective

\section{Adopting the blended learning model: critical success factors}

Based on the analysis of some past experiences in the adoption of blended learning models [49], educational institutions that intend to adopt a blended learning model should carefully consider, among others, the following three critical success factors [50]. These are common factors to any level of education (e.g. undergraduate, graduate, executive), and type of educational institution (e.g. private or public).

The first factor relates to the definition of a strategy. To make it successful, the adoption of the blended learning model must be part of the educational institution's strategy. This is a condition that allows the blended learning experience to exploit the full potentiality of the host educational institution [51].

The second factor is related to the organizational support, understood as facilitating conditions. We consider facilitating conditions as the degree to which individuals believe that social resources exist to support them in learning in a blended setting. Facilitating conditions have been widely analysed in the workplace setting and have been conceptualized in terms of training and provision of organizational support [52, 53].

The third factor refers to the organizational capabilities to effectively execute and deliver a blended learning program. Here organizational capabilities are understood as the 
organization's ability to manage all the people involved in a learning process to gain advantages [54]. In other words, the value for stakeholders comes from putting management practices into place that meet stakeholders' (specifically learners'), needs. So, a capable educational organization focuses not just on building internal efficiencies but on translating those efficiencies into benefits to learners. Among the organizational capabilities we highlight the followings as particularly significant: being able to design a program according to a blended model, that requires instructional designers who are competent with this specific learning model; faculty members have to be prepared in structuring and developing learning initiatives that can make effective use of the all potentiality and benefits offered by the blended model - thus, the interaction between faculty members and instructional designers is essential; being able to design and put in place technological infrastructure and solutions that are most appropriate for guaranteeing the achievement of the learning goals as formulated by the blended model; being able to effectively manage the communication process with all the relative stakeholders thus, it's a useful idea to create a specific narrative for each homogeneous group of stakeholders. This narrative allows creating and using a common vocabulary and definitions, which in turn facilitates the acceptance by stakeholders.

\section{Change process}

Following the above considerations, the use of technology for educational purposes is pushing educational institutions to rethink and change the traditional way of designing and delivering their learning programs [55]. And the change process involved in switching from a 'classic' institution based on face-toface faculty-student interaction to an innovative institution capable of making the most out of the potential of blended-learning environments is far from simple. Thus, it is important for faculty members - and students as well - to be able to make an effective use of technologies for supporting the educational process and ultimately achieving the set learning goals. Showing a low level of the capability in using such technologies represents a major obstacle in the proper adoption of a blended learning environment. Actually, this risk can be experienced not only in the blended learning model, but also in any other types of online or e-learning models. So, focusing on the blended learning environment faculty members not only face the change involved in learning how to use the technology pro-posed (e.g. moodle, tokbox...) but, perhaps more importantly, they face the challenge of adopting learner-centred practices, something different research has shown to be far from easy $[2,56]$.
In order to make this transition possible, organizations and institutions interested in adopting blended learning models must have a clear vision and a strong support from the various stakeholders involved in the change process [57], and be ready to exercise what Garrison \& Vaughan mention [58] call sustained collaborative leadership. Going beyond effective and inspirational communication strategies, such leadership involves the design of an adequate action plan which, among others, have the following interconnected dimensions into account: desired change speed and desired change scope, policy-making strategy and characteristics of faculty body.

We start with the last dimension, the characteristics of the school's faculty body, which we consider key [59]. Faculty are of course one of the essential stakeholders in the process since they will be protagonists in their classes and if they are not convinced of the benefits of the new blended learning approach this will never be adequately explained to the learners (a sine qua non condition for learner engagement). Among the aspects playing a key role in the change management process we find faculty talent (i.e., their adjustment to the knowledge and competence profile the School development will need), their stage in their academic career (the more initial in their career the more flexible they may be towards change and the closer they can be to learners' mind-set), and of course their disposition towards change, given their history in the institution and their vision of where the institution should head towards in the future.

Secondly, assessing the necessary speed and scope whereby the change needs to be effected will be essential when making decisions as to the ways to go about change implementation: the more urgent the change, the more top-down the leadership for change need to be, and the

higher the connection faculty have with the institutional vision, with more ease will the top-down approach be perceived and experienced. Needless to say, and thirdly, if the scope of change focuses on a reduced number of programs (as opposed to all the programs of the institution), a top-down but also a bottom-up approach in change leadership can be applied, as the complexity of the process is reduced, especially if the sense of urgency is decreased. 
Finally, the policy-making strategy will need to have all the above in mind to allocate the necessary resources to provide for adequate faculty support and development and to put into effect incentives for blended learning experiences (e.g., ways of providing faculty with the necessary recognition for their willingness to contribute to the institutional change).

\section{Make the change happen: a proposed framework}

In this section we intend to propose some recommendations to educational institutions' decisionmakers and/or change agents in order to make the abovedescribed change become a reality. Specifically, we propose an educational change framework that is based on the Kotter's framework [60]. Our framework consists of the following five steps, which are presented in table 5.1 below.

The first step is to make the need for change visible. The more visible the need for change, the higher the sense of urgency $[60,61]$. In other words, when people have a clear understanding of why the change is necessary then they better contribute to the change process. So, creating the sense of urgency is extremely relevant for activating the change process. How to create the need for change? The change agent has to collect data, facts and evidences that demonstrate how and why the blended model can be more effective than the e-learning or other models, and $\mathrm{s} /$ he needs to make the case regarding the what blended learning will bring to the School's value proposition. When overestimated, this step has a strong negative influence on the change process.

Once the need for change has been demonstrated, it is time to elaborate on what the changed educational model should articulate around. In order to do this, the change agent has first to create a team whose members have a high level of credibility, are open to explore and innovate, and able to influence other stakeholders in the institution (particularly, stakeholders who are resistors). One of the first tasks for the change team is the definition of link between the blended learning strategy and the institution educational strategy. This means the change team must elaborate and define how the blended model can be successful in the organization by connecting it with the institution's educational strategy. Such model should not only consider which tools would be most useful, but it should also consider providing a framework of reference regarding the ways in which those tools may be used in particular classroom settings to enhance learners' learning and, not just any kind of learning but that which connects with the exit profile that aligns with the School mission.

Then, the change team has to formally define the educational paradigm, and its relative execution plan. Educational paradigm and execution plan are keys of a change process since on too many occasions changes remain at the level of discourse. One of the dimensions to have in mind when designing this execution plan is the resources that will be necessary to equip the institution with the adequate technology and, even more importantly, to ensure there is a team of experts in technologyenhanced learning, and blended learning models and methodologies to provide faculty with the necessary support to make the change possible. While implementing the plan, and ac-cording to the ongoing results, the team makes any necessary adjustment to make the adoption of the blended model successful.

As part of the implementation of the plan, the change agent along with the change team describes and presents the blended learning model (how it works, advantages and key success factors) to all institutional stakeholders, keeping them continuously informed on the change progresses. This is a set of massive and intensive communication activities, to act along with the entire change process. Communication has to be properly designed according to the different targets, and the possibility of using pilot projects to support and illustrate the tangibility of the alleged value brought by the new model will be key. Underestimating the power of the communication can be the reason why the educational change process fails.

\section{Table 2. Steps in the educational change framework}

\begin{tabular}{|ll|l|}
\hline \multicolumn{2}{|c|}{ Steps } & \multicolumn{1}{c|}{ Actions } \\
\hline 1. & $\begin{array}{l}\text { Make the } \\
\text { need for } \\
\text { change } \\
\text { visible }\end{array}$ & $\begin{array}{l}\text { * } \text { collect data, facts and evidences } \\
\text { that demonstrate how and why the } \\
\text { blended model can be more } \\
\text { effective than the e-learning one } \\
\text { * } \text { make the case regarding the what } \\
\text { blended learning will bring to the } \\
\text { School's value proposition. }\end{array}$ \\
\hline 2. & $\begin{array}{l}\text { Create a } \\
\text { change team }\end{array}$ & $\begin{array}{l}\text { * Identify faculty members with a } \\
\text { high level of credibility, who may be } \\
\text { open to explore and innovate, and } \\
\text { able to influence other stakeholders } \\
\text { in the institution (particularly, } \\
\text { stakeholders who are resistors) }\end{array}$ \\
\hline 3. & $\begin{array}{l}\text { Define } \\
\text { new } \\
\text { educational } \\
\text { paradigm }\end{array}$ & $\begin{array}{l}\text { * elaborate and define how the } \\
\text { blended model can be successful in } \\
\text { their organization by connecting it } \\
\text { with the institution's educational } \\
\text { strategy, } \\
{ }^{*} \text { consider which tools would be }\end{array}$ \\
\hline
\end{tabular}




\begin{tabular}{|c|c|}
\hline & $\begin{array}{l}\text { most useful, } \\
\text { * provide a framework of reference } \\
\text { regarding the ways in which those } \\
\text { tools may be used in particular } \\
\text { classroom settings to enhance } \\
\text { learners' learning and, not just any } \\
\text { kind of learning but that which } \\
\text { connects with the exit profile that } \\
\text { aligns with the school mission. }\end{array}$ \\
\hline $\begin{array}{l}\text { 4. Design and } \\
\text { implement } \\
\text { the execution } \\
\text { plan }\end{array}$ & $\begin{array}{l}\text { * elaborate a resource plan that will } \\
\text { be necessary to equip the institution } \\
\text { with the adequate technology } \\
\text { * ensure there is a team of experts } \\
\text { in technology-enhanced learning, } \\
\text { and blended learning models and } \\
\text { methodologies to provide faculty } \\
\text { with the necessary support to make } \\
\text { the change possible. }\end{array}$ \\
\hline $\begin{array}{l}\text { 5. Communicate } \\
\text { the new } \\
\text { educational } \\
\text { paradigm }\end{array}$ & $\begin{array}{l}\text { * design the communication } \\
\text { strategy to present the blended } \\
\text { learning model: how it works, } \\
\text { advantages and key success } \\
\text { factors. } \\
\text { * incorporate in this communication } \\
\text { examples of the pilot editions of the } \\
\text { educational model run with selected } \\
\text { faculty. }\end{array}$ \\
\hline
\end{tabular}

\section{Conclusions}

This paper has contended that blended learning is increasingly gaining support as the model of the future in higher education. As we have seen, blended learning not only provides a series of advantages as compared to fully e-learning education (decreased learners' perception of instructional difficulty or excessive workload, increased perception of blended learning as excellent learning experiences, decreased withdrawal from learners) but it may also contribute to add value to face-to-face live class sessions, by enhancing learners' preparation for those via online activities and resources.

All these reasons suggest that blended learning will increasingly regarded as an approach to be incorporated in higher education institutions, especially in those international ones in constant quest for excellence and innovation in the learning experiences they propose to their students. And these institutions will no doubt face the challenges outlined when implementing the change management processes necessary for blended learning to bring the expected value to their programs. As Garrison \& Vaughan mention [58], sustained collaborative leadership with the components mentioned above will be necessary to introduce blended learning effectively. Such collaborative leadership should, however, be articulated around a clear and sound change management framework such as the one proposed in this paper, which will allow for the educational change brought by the introduction of the blended learning model to become a reality.

\section{References}

[1] Caporarello, L., Sarchioni, G. (2014) E-learning: the recipe for success. Journal of e-learning and Knowledge Society, 10(1): 107-118

[2] CAporarello, L., SARChioni, G. (2012) Does technologymediated learning matter for effective teams? In Spagnoletti, P. [ed.], Organizational change and information systems (Heidelberg, Germany: Springer)

[3] Nemanich, L., Banks, M., \& Vera, D. (2009) Enhancing knowledge transfer in classroom versus online settings: The interplay among instructor, student, content, and context. Decision Sciences Journal of Innovative Education, 7(1): 123-148

[4] Song, L., Singleton, E., Hill, J. R., \& KoH, M. H. (2004) Improving online learning: Student perceptions of useful and challenging characteristics. The Internet and Higher Education, 7(1): 59-70

[5] Willams, P. J. [ed.] (2012) Technology Education for Teachers (Germany: Springer)

[6] Dunken, M. J. (1983) A review of research on lecturing. Higher Education Research and Development, 2(1): 63-78

[7] Milliken, J., \& Barnes, L. P. (2002) Teaching and technology in higher education: Student perceptions and personal reflections. Computers \& Education, 39(3): 223235

[8] RAMSDEN, P. (1992) Learning to teach in higher education. (London: Routledge)

[9] ONG, C.-S., \& LAI, J.-Y. (2006) Gender differences in perceptions and relationships among dominants of elearning acceptance. Computers in Human Behavior, 22(5): 816-829

[10] SAAde, R., He, X., \& KirA, D. (2007) Exploring dimensions to online learning. Computers in Human Behavior, 23(4): 1721-1739

[11] WANG, Y.-S., WANG, H.-Y., \& SHEE, D. Y. (2007) Measuring e-learning systems success in an organizational context: Scale development and validation. Computers in Human Behavior, 23(4): 1792-1808

[12] Yang, X., Li, Y., Tan, C.-H., \& TeO, H.-H. (2007) Students' participation intention in an online discussion forum: Why is computer-mediated interaction attractive? Information \& Management, 44(5): 456-466

[13] Guri-Rosenblit, S. (2005) Eight paradoxes in the implementation process of eLearning in higher education. Higher Education Policy, 18(1): 5-29

[14] Kearsley, G. (1998) A Guide to Online Education, Online:

http://gustavolarriera.tripod.com/doc/tech/online.htm (last access on 16 May 2015)

[15] Liaw, S. S., Huang, H. M., \& Chen, G. D. (2007) Surveying instructor and learner attitudes toward elearning. Computers \& Education, 49(4), 1066-1080

[16] Terry L. (2000) Get Smart Online, Upside, 12(5): 162164

[17] Rosenberg M. J. (2001) E-Learning. Strategies for delivering knowledge in the digital age (New York: McGraw-Hill)

[18] Welsh E. T., Wanberg C. R., Brown E. G., Simmering M. J. (2003) E-learning: Emerging uses, empirical results 
and future directions. International Journal of Training and Development, 7(4): 245-258

[19] GRAFF, M. (2003) Learning from web-based instructional systems and cognitive style. British Journal of Educational Technology, 34(4): 407-418

[20] Liaw, S. S. (2008) Investigating students' perceived satisfaction, behavioral intention, and effectiveness of elearning: A case study of the blackboard system. Computers \& Education, 51(2): 864-873

[21] Zhang, D., Zhou, L., Briggs, R. O., \& Nunamaker Jr, J. F. (2006) Instructional video in e-learning: Assessing the impact of interactive video on learning effectiveness. Information \& Management, 43(1): 15-2

[22] BALdwin-Evans K. (2004) Employees and eLearning: what do the end-users think? Industrial and Commercial Training, 36(7): 269-274

[23] Selim H. M. (2007) Critical success factors for e-learning acceptance: Confirmatory factor models. Computers and Education, 49(2): 396-413

[24] Otte, G., Benke, M. (2006) Online learning: New models for leadership and organization in higher education. Journal of Asynchronous Learning Networks, 10(2): 23-31

[25] Daniels, H. L., Moore D. M. (2000) Interaction of cognitive style and learner control in a hypermedia environment. International Journal of Instructional Media, 27(4): 1-15

[26] ОH, E., LIM, D. H. (2005) Cross relationships between cognitive styles and learner variables in online learning environment. Journal of Interactive Online Learning, 4(1): 53-66

[27] Rodrigues J.J.P.C., SABino F.M.R., Zhou L. (2011) Enhancing e-learning experience with online social networks. IET Communications, 5(8): 1147-1154

[28] Sitzmann, T., Kraiger, K., Stewart, D., Wisher, R. (2006) The comparative effectiveness of web-based and classroom instruction: A meta-analysis. Personnel Psychology, 59(3): 623-664

[29] Zhang, D. S., ZhaO, J. L., Zhou, L., \& NunamakeR, J. F. (2004) Can e-learning replace classroom learning? Communications of the ACM, 47(5): 75-79

[30] BRUCKMAN, A. (2002) The future of e-learning communities. Communications of the ACM, 45(4): 60-63

[31] Piccoli, G., Ahmad, R., \& Ives, B. (2001) Web-based virtual learning environments: A research framework and a preliminary assessment of effectiveness in basic IT skills training. MIS Quarterly, 25(4): 401-426

[32] Decker, T., Frailey, D., McNell, E., \& Mould, D. (2000) Forum: debating distance learning. Communications of the ACM, 43(2): 11-15

[33] Fontaine, G. (2002) Presence in "Teleland." In RudestaM, K. E. and J. Schoenholtz-Read, J. [eds.], Handbook of Online Learning: Innovations in Higher Education and Corporate Training (Thousand Oaks, CA: Sage)

[34] Lee Y. H., Hsieh Y. C., Hsu C. N. (2011) Adding Innovation Diffusion Theory to the Technology Acceptance Model: Supporting Employees' Intentions to use E-Learning Systems. Educational Technology \& Society, 14(4): 124-137

[35] Martyn, M. (2003) The hybrid online model: good practice. Educause Quarterly, 26(1): 18-23

[36] Jennings, A., Mullally, A., O'Connor, C., \& Dolan, D. (2006) Is the jury still out for "blended learning"? - use of a web-based collaborative teaching platform. In FILLIPE, J., Cordeiro, J., Pedrosa, V. [eds.], Web information systems and technologies (Heidelberg, Germany: Springer)
[37] So, H., \& BRush, T. A. (2008) Student perceptions of collaborative learning, social presence and satisfaction in a blended learning environment: relationships and critical factors. Computers \& Education, 51(1): 318-336

[38] Reid-Young, A. (2003) The key to e-learning is blearning, $\mathrm{HCi}$ Journal of Information Development. available online at: https://www.hci.com.au/b-learning (last access on 16 May 2015)

[39] Graham, C. R. (2013) Emerging practice and research in blended learning. In MoOre, M. G. [ed.], Handbook of distance education, 3rd ed. (New York, NY: Routledge)

[40] Reece, M., Lockee, B. (2005) Improving training outcomes through blended learning. Journal of Asynchronous Learning Networks, 9(4): 49-57

[41] Picciano, A. G. (2006) Blended learning: Implications for growth and access. Journal of Asynchronous Learning Networks, 10(3): 85-91

[42] Singh, H., ReEd, C. A. (2001) White Paper: Achieving Success with Blended Learning. ASTD State of the Industry Report. (Alexandria, VA: American Society for Training \& Development)

[43] Thorne, K. (2003) Blended Learning: How to Integrate Online \& Traditional Learning (London: Korgan Page Ltd)

[44] AMBIENT InSIGHT (2011) Learning and performance technology research taxonomy (Monroe, WA: Ambient Insight)

[45] Moskal, P., Dziuban, C., Hartmanet, J. (2013) Blended learning: A dangerous idea? Internet and Higher Education, 18: 15-23

[46] Glazer, F. S. (2012) Introduction. In Glazer, F. S. Blended learning; Across the disciplines, across the academy (Sterling, VA: Stylus Publishing, LLC)

[47] ReICH, J. (2015) Rebooting MOOC Research, Science 347(6217): 34-35

[48] Norberg, A., Dziuban, C. D., Moskal, P. D. (2011) A time-based blended learning model. On the Horizon, 19(3): 207-216

[49] Garrison, D. R. \& Vaughan, N. D. (2007) Blended learning in higher education: framework, principles, and guidelines (San Francisco, CA: Jossey-Bass)

[50] Stacey, E., Gerbic, P. (2008) Success factors for blended learning. In Hello! Where are you in the landscape of educational technology? Proceedings ascilite Melbourne. available online at: http://www.ascilite.org.au/conferences/melbourne08/procs/ stacey.pdf (last access on 16 May 2015)

[51] Graham, C. R., Woodfield, W. \& Harrison, J. B. (2013) A framework for institutional adoption and implementation of blended learning in higher education. The Internet and Higher Education, 18: 4-14

[52] Gallivan, M. J., Spitler, V. K., Koufaris, M. (2005) Does Information Technology Training Really Matter? A Social Information Processing Analysis of Coworkers' Influence on IT Usage in the Workplace. Journal of Management Information Systems, 22(1): 153-192

[53] Venkatesh, V., Morris, M. G., Davis, G. B., \& Davis, F. D. (2003) User acceptance of information technology: Toward a unified view. MIS Quarterly, 27(3): 425-478

[54] UlRICH, D. \& LAKE, D. (1991) Organizational capability: creating competitive advantage. Academy of Management Executive, 5(1): 77-91

[55] Janicki, T., Steinberg, G. (2003) Evaluation of a computer-supported learning system. Decision Sciences Journal of Innovative Education, 1(2): 203-223 
[56] Hargreaves, A. (1998) The emotions of teaching and educational change. In Hargreaves, A., Lieberman, A., Fullan, M. HoPKINS, D. [eds] International handbook of educational change (Dordrecht: Kluwer)

[57] Dziuban, C., Hartman, J., Cavanagh, T., Moskal, P. (2011) Blended courses as drivers of institutional transformation. In KiTCHENHAM, A. [ed.] Blended learning across disciplines: Models for implementation (Hershey, PA: IGI Global)

[58] Garrison, D. R. \& VAughan, N. D. (2021) Institutional change and leadership associated with blended learning innovation: two case studies. Internet and Higher Education, 18: 24-28

[59] Porter, W. W. \& Graham, C. R. (2015) Institutional drivers and barriers to faculty adoption of blended learning in higher education. British Journal of Educational Technology, doi: 10.1111/bjet.12269

[60] Kotter, J. P. (2007) Leading Change: Why Transformation Efforts Fail, Harvard Business Review

[61] Ginsberg, A. \& Venkatraman, N. (1995) Institutional initiatives for technological change: from issue interpretation to strategic choice. Organizational Studies, 16(3): $425-448$ 